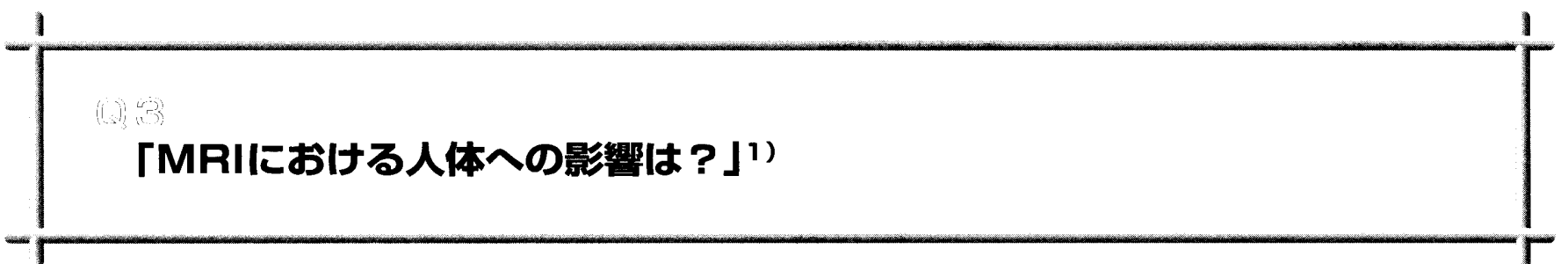

\section{Ans (3)}

MRIには, 静磁場, 変動磁場, 高周波 $(\mathrm{RF})$ の作用 がある．診断用MRI装置を使用する際には，以下の人 体への影響が考えられる。

1. 静磁場の力学的作用

2. RFによる発熱

3. 傾斜磁場の変動による神経刺激

4. 傾斜磁場の騒音

5. 妊婦のMRI検査

6. 装着している金属の安全性

\section{1. 鲜磁場の力学的作用}

静磁場の安全管理で問題となるのは，強磁性体に対 する力学的作用である。これは, 過去にいくつかの事 故例がある。一方，静磁場が人体に直接及ぼす生物学 的作用については，診断用MRI装置で問題となった報 告はない，当然のことながら，強磁性体は，高い静磁 場強度で，マグネットに近く(抢抢むね距離の三乗に 反比例)，大きいほど強い力を受ける。静磁場の力学 的作用による事故を防止するために，MR安全標識， 漏洩磁場分布，立入制限区域などを明示し，検査室に 入る際には細心の注意を払うようにしなければならな い.

\section{RFによる発熱}

MRI検査中に熱く感じるのは，RFによる発熱作用 が原因の一つである。もちろん「熱い」という感覚は， RFだけでなく検查室温，マグネット内の空気の循環 量，被検者自身の体調等にも依存する，RFによって 導電体である人体に生じた渦電流のジュール熱は，単 位重量当たりの熱吸収比(SAR: specific absorption Rate, W/kg)によって評価する。

RFエネルギーが熱に変換された割合が大きい場合 (大きなSAR)，「熱い」と感じることはあり得るが，そ れでは体温が大きく上昇するかといえば，診断用MRI 装置に打いては，生体の放熱機能のために体温上昇は ほとんどみられない，皮膚温が上昇した例は多数報告 されているが，それは生体が調節可能な範囲にあり， 結局，RFによって熱くは感じても生体に害を及ぼす 可能性は通常極めて低いと考えられる．FDAの基準値 よりもはるかに高いSARでも問題ないという報告が多
く出ている．ちなみに傾斜磁場の変動によって生じる 渦電流の熱作用 (間接作用) は, RFのSARと比較し て，大きくても百万分の 1 以下なので問題とならな い.

SARは，静磁場強度の二乗に比例し，大きな被検体 で電気伝導率が高い組織ほど大きくなる。さらに，人 体のような不均一な組織の場合，局所SARはより大き くなる。またSARは，フリップ角度の二乗およびスラ イス数やRFパルス印加時間に比例し，繰り返し時間 に反比例する。 QD型送信コイルは，リニア型送信コ イルよりもSARを約 $1 / 2$ に低減できる。

SARは，コイルのQより算出する方法や，定常波比 加算出する方法 (NEMA, IEC) に加えて, 温度变化 を測定する方法(NEMA)や，生体各部のSARの分布を シミュレートする手法など，さまざまな測定法や解析 法によって評価されている。

\section{3. 傾斜磁場の変動による神経刺激}

単位時間当たりの磁場(傾斜磁場)の変動による効果 を，「dB/dt effect」と呼んでいる．ファラデーの誘導法 則によって導電体である人体には， $\mathrm{dB} / \mathrm{dt}$ の大きさに 比例して電圧, 電流が生じる。通常, $\mathrm{dB} / \mathrm{dt}$ は1 1 T $/$ secなので生物学的作用を観察できないが, $\mathrm{dB} / \mathrm{dt}$ が 60T/secになると，顔や背中の筋肉において本梢神経 刺激を受けた報告を含め種々の報告がある。もちろん 刺激が大きくなるのは，傾斜磁場の変動が相対的に大 きくなる均一磁場球の端の方であり，傾斜磁場の直線 性が広範囲に保証されているのなら体軸方向において より大きな変動磁場を受けることになる。

MRI検査の際に，刺激を受けたという報告をごく稀 に耳にすることがある。一般的な規制值(例：立ち上 がり時間 $\mathrm{T}>120 \mu \mathrm{sec} て ゙ \mathrm{~dB} / \mathrm{dt}<20 \mathrm{~T} / \mathrm{sec})$ 内において，神 経刺激が生じるとは考えにくい。しかしながら，EPI 等の超高速シーケンスで強い変動磁場を与え，かつ被 検者が末梢神経刺激に大変敏感な場合には，変動磁場 によって刺激を受けないとは断言できない。ただここ の変動磁場が人体に与える影響を定量化するのは個体 差や心的要因も混在するため困難である．なお，MRI 装置で使用しているRFには神経刺激作用はない。

$\mathrm{dB} / \mathrm{dt}$ を測定する方法は，NEMAやIECから提唱され ている(小円形サーチコイルで測定)。一般に, FOV, 
スライス厚, TE，エコー間隔を小さくするほど，高 いslew rate $(\mathrm{T} / \mathrm{m} / \mathrm{s})$ が必要となるので, $\mathrm{dB} / \mathrm{dt}$ は大きく なる．高速なパルスシーケンスほど $\mathrm{dB} / \mathrm{dt}$ は大きくな るが, 超高速シーケンスでもspiralやburstはそれほど 大きくはない.

\section{4. 傾斜磁場の騷音}

MRI装置の主要な騒音は, 傾斜磁場コイル電流の才 ンオフによって発生する。MRI検査時の騷音は，被検 者を不快にしたり対話を困難にするだけでなく，可逆 性の聴力損失を来したり，さらには高い音に過敏な被 検者が強い騒音によって永久的聴力損失を来す可能性 を示した報告もある。

騒音を低減させるために耳栓やそれに類似する装具 の使用とともに，さまざまな手法が開発実用化されて いる，その反面，各種の機能画像を得るために，高速 撮像を達成させる高い傾斜磁場の能力が必要とされて きており，依然として騒音の影響は無視できない。騒 音基準の根幹となるOSHAの規制値は，全体の $85 \%$ の みを著しい聴力損失から守るレベルでしかなく, MRI の騒音が聴力に影響するという報告がある以上，騒音 が規制值内であっても，検查時に適切な減音法を使用 することが望ましい。

\section{5. 妊㛿のMRI検童}

妊婦のMRI検査に関してFDAや厚生省では，胎児や 乳児のMRI検査の安全性は確立されていないことを表 示する必要があるとしている．MRIの胎児に与える障 害に関しての研究は完全でないものの，奇形の可能性 を示す研究はいくらか行われている。電磁場と発育中 の胎児との相互作用において，生物学的な悪影響の可 能性を示した報告もいくつかある．特に，第 1 三半期 間 (妊張初期の 3 力月間)胎巟の分裂中の細胞ほど, さ まざまな物理作用を受けやすいので，この時期におけ るMRI検査は慎重でなければならない。いずれにして も，妊張の疑いのある患者は，MRI検査によって得ら れる恩恵と危険性を評価するために，事前に妊娠して
いるか否かを必ず確認して捻く必要がある。なお，金 属毒性を下げるためにキレート化したガドリニウム造 影剂の，妊婦(胎児)に対する影響は確立されていな い. 胎盤を通過した際にキレートが外れる可能性も指 摘されているので，使用を控えるべきである。

次に，放射線技師，看護婦，看護助手，医師など， 頻繁にMRI検査室に出入りする可能性のある女性が, 妊娠している場合はどうであろうか．統計的調査にお いては，MRI検査に携わっているスタッフが妊娠して いても有意な影響を認められなかったという報告があ るが，生物学的に安全であることの立証は今後も困難 と考えられる。日本において現時点では明確な規定が ないので，これらの事実を踏まえて各施設の責任者が スタッフに対して説明と同意を得たうえで，検査に携 わるか否かを決定するのが妥当ではないかと考える。

\section{6. 装着している金属の安全性}

金属装着患者の検査に関してメーカに問い合わせる と，責任の所在の問題(PL法)もあり大部分が金属装着 患者の検査については否定的であるが，MRI検査を必 要に迫られる場合がある，実際には，診断用MRI装置 に拈いて，画質の低下は生じても安全性という観点か ら問題ない金属部品と, 絶対に検査時に脱着しなけれ ばならない金属部品がある。最終的には，MRI検査に よって患者が得る利益と，検相によって生じる危険性 を天秤に掛けることになるが，そのためには，事前に 被検者か装着している金属または医療器具の安全性を 掌握しておかなければならない，体に装着している金 属を確認するためには金属探知器の使用も有効である が，小さな金属や深部にある金属等は検知できない場 合があるので，金属探知器は必ずしも絶対的でないこ とを十分に留意しておかなければならない。

\section{参考文献}

1）宮地利明：装置の安全基準(人体への影響)。放射線医療技 術学叢書「MR撮像技術一よりよい画像を得るために」, pp.238-248, 日本放射線技術学会 放射線撮影分科会, 京 都, (2000).

（回签者：宮地）

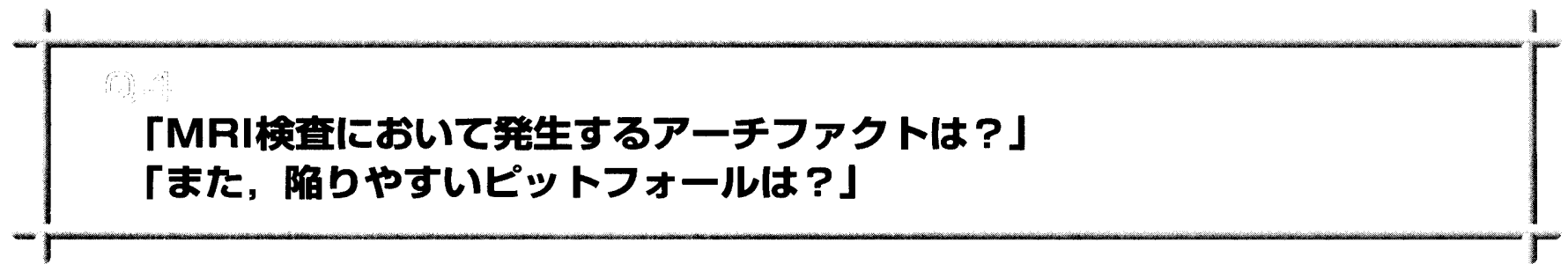

\section{Ans (4)}

\section{MRIで認められるartifact}

MRIには，ハードウェアに起因するartifact，データ
収集時に起因する artifactおよび，被写体の動きに起因 する artifactと多くの診断に支障を来すartifactが存在す る。これらのartifactは，発生する方向 $(\operatorname{artifact} の$ 影響 